\title{
A decade of change: The past 10 years of Taiwan higher education institutions
}

\section{Ching, Gregory S. $\bowtie$}

Graduate Institute of Educational Leadership and Development

Research and Development Center for Physical Education, Health, and Information Technology

Fu Jen Catholic University, Taiwan (gregory_ching@yahoo.com)

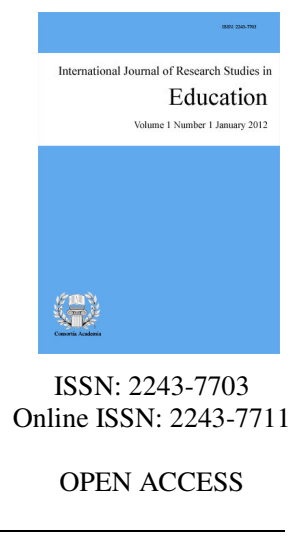

Received: 20 May 2020

Revised: 30 November 2020

Accepted: 6 December 2020 DOI: $10.5861 /$ ijrse. 2020.5888

\section{Abstract}

Taiwan higher education institutions are facing great challenges arising from both global and local sources. Global pressures brought forth by need to have a presence within the global university ranking systems (or league tables), while local pressures that stem from the declining number of incoming students. To remedy these dilemmas, the Taiwan Ministry of Education and higher education institutions are working hand in hand focusing on both policy and financial aspects of the academe. This presentation shall focus on providing an overview of what has happened for the past decade, while also summarizing past and ongoing strategies such as institutional mergers, rebranding/transformation of degree programs, changing academic profession, further expansion of international enrollments, and developing the quality of research through the establishment of institutional review boards (IRB) or research ethics committee (REC), and institutional research (IR) centers. Ultimately Taiwan higher education institutions are seeking to expand its institutional competitiveness while struggling with the myriad challenges of the academe.

Keywords: governance; policy; restructure; neoliberal management; competitive advantage; institutional performance; funding 


\section{A decade of change: The past 10 years of Taiwan higher education institutions}

\section{Introduction}

Similar with most countries in the Asian region, the global university ranking systems or the university league tables have greatly influenced Taiwan higher education institutions (HEIs) (Lo, 2014). With the notion that becoming a world-class university is synonymous to being able to make it into the list of the top tier institutions within the league tables (Hazelkorn, 2015; Salmi, 2009); in effect, HEI funding policy changes in Taiwan are being tailored towards enhancing scores within these league tables' criteria (Deem, Mok, \& Lucas, 2008; Grewal, Dearden, \& Llilien, 2008; Lynch, 2014; Mok \& Chan, 2008). However, such policy changes have been faced with outcry of inequality (Hou, Ince, \& Chiang, 2013; Song \& Tai, 2007), more specifically, is with the strong emphasis on academic publication within the journals listed in the Thomson Reuter's ISI citation databases (Ching, 2013a, 2013b; Chou, Lin, \& Chiu, 2013; Huang, 2009).

Emphasis on publishing within these journals has been tainted with both facts and fallacy, such as the criteria for research grants and awards, promotion of faculty, to the graduation requirement of some doctoral programs. With these having said, it would seem that Taiwan HEIs are being challenged to perform beyond their local boundaries (e.g. publishing in a non-native language such as English instead of Chinese). More important, is that, since most of the available funding is formulated in such a way that HEIs should outperform each other (e.g. the higher number of publications translate to larger amount of funding), it is therefore imperative that universities comply with the rules, so as to able to get into the number game.

Looking within the local situation, Taiwan is plague with a serious problem of declining birth rate. According to the National Statistics office of Taiwan, the annual birthrate has been declining since 1985. Record shows that the figure of 344,101 childbirths in 1985 steadily dropped to more than half with the lowest of 166,473 childbirths in 2010, however, with some upward surges during the Chinese Zodiac year of the Dragon (e.g. 1988, 2000, and 2012, see figure 1 for more details). Also note the lowest during the Chinese Zodiac year of the Tiger (e.g. 1986, 1998, and 2010).

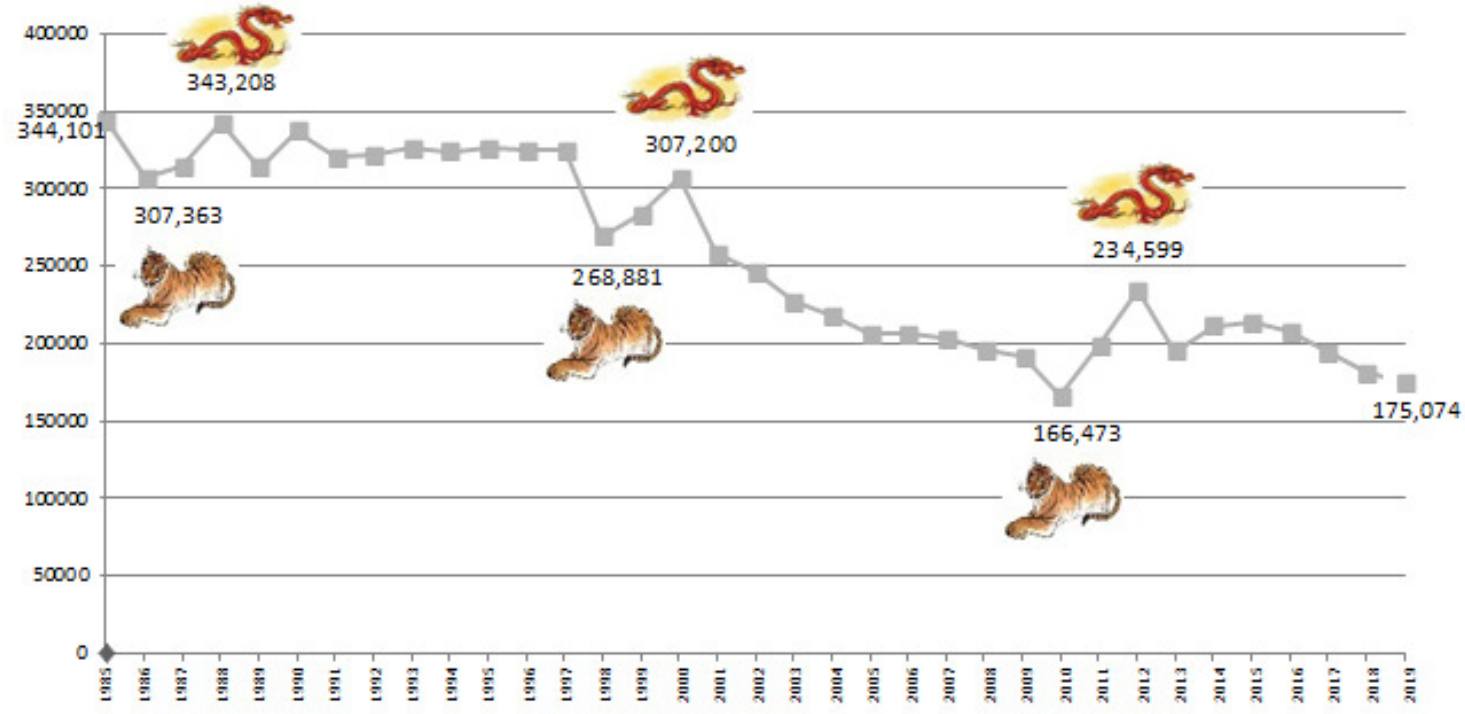

Figure 1. Taiwan declining birthrate.

Note. Dragon and tiger denotes Chinese Zodiac for the specific year.

Source. Taiwan Statistics (https://www.stat.gov.tw) 
A decade of change: The past 10 years of Taiwan higher education institutions

To increase the population, provisions for monetary and other incentives are placed to encourage childbirths (Branigan, 2012), still, this persisting downward spiraling birth rate, would translate to lesser and lesser students. Hence, this situation would cost a lot of future financial difficulties for academic institutions (Chen \& Chang, 2010). It is expected that by the opening of the school year 2016/17 in September 2016, there will be huge drop of around 20,000 university freshmen enrollees (Chang, 2014). In reality, during the 2017/18 school year a dropped of around 30 to 32 percent was felt (Fulco, 2018). By 2028, there will be less than 160,000 new freshmen students left, causing much concern within the academia (Green, 2020).

Table 1 shows the past, current, and projected numbers of incoming freshmen students from the Taiwan Ministry of Education (MOE) together with the existing number of HEIs. Note the steady drop of around 10,000 students per school year starting 2018, with the estimated lowest number of only 159,000 students in 2028. Worth looking into is the actual impact of the decreasing number of students, analyzing the data shows some alarming issues. Table 2 shows that the enrollment changes are mostly affecting private HEIs. In other words, the decreasing number of incoming students is mostly reflected in private HEIs. In reality, when given a chance, students would flock to the national (public) HEIs; as compared to the higher tuition requirement in private institutions, in addition to the somewhat "high" status attached to studying in a national (public) HEI.

\section{Table 1}

Past, current, and projected number of incoming university first-year students

\begin{tabular}{ccc|cc}
\hline School year & Incoming freshmen & Number of HEIs ${ }^{*}$ & School year & Incoming freshmen \\
\hline 2001 & 276,000 & 154 & 2020 & 214,000 \\
2006 & 267,000 & 163 & 2021 & 204,000 \\
2011 & 276,000 & 163 & 2022 & 192,000 \\
2012 & 278,000 & 162 & 2023 & 187,000 \\
2013 & 271,000 & 161 & 2024 & 181,000 \\
2014 & 272,000 & 159 & 2025 & 178,000 \\
2015 & 273,000 & 158 & 2026 & 178,000 \\
2016 & 254,000 & 158 & 2027 & 173,000 \\
2017 & 239,000 & 157 & 2029 & $159,000^{* *}$ \\
2018 & 252,000 & 153 & 2030 & 165,000 \\
2019 & 243,000 & 152 & 193,000 \\
\hline Note. ${ }^{*}$ Including all public, private, universities, technical vocational universities, and colleges. & \\
F* Projected lowest number of students.
\end{tabular}

Source. https://stats.moe.gov.tw

\section{Table 2}

Actual freshmen enrollment from SY 2010-2015

\begin{tabular}{c|cc|cc|cc}
\hline School year & Public & \% change & Private & \% change & Total & $\%$ change \\
\hline 2010 & 66,027 & $0.25 \%$ & 180,247 & $3.87 \%$ & 246,274 & $2.79 \%$ \\
2011 & 66,622 & $0.90 \%$ & 187,260 & $3.89 \%$ & 253,882 & $3.09 \%$ \\
2012 & 67,298 & $1.01 \%$ & 188,400 & $0.61 \%$ & 255,698 & $0.72 \%$ \\
2013 & 67,362 & $0.10 \%$ & 181,599 & $-3.61 \%{ }^{*}$ & 248,961 & $-2.63 \%$ \\
2014 & 68,344 & $1.46 \%$ & 182,024 & $0.23 \%$ & 250,368 & $0.57 \%$ \\
2015 & 68,917 & $0.84 \%$ & 179,759 & $-1.24 \%{ }^{*}$ & 248,676 & $-0.68 \%^{*}$ \\
\hline
\end{tabular}

Note. ${ }^{*}$ Negative value denoting the number of students dropped. Source. https://stats.moe.gov.tw

Furthermore, besides the decreasing new entrants students, overall student population of the private HEIs are steadily decreasing, while minimal impact are felt for the national institutions. In actuality, it is only these few years that public HEIs are having a decreased in overall student population (a decrease of around .2 to .3 percent). Table 3 shows that during the 2011/12 school year, there were around 753,935 students enrolled in private universities, however this went down to around 643,855; a decrease of 110,080 students, an almost drop of $15 \%$. While the public or national universities from 279,050 to 288,663 ; an actual increase of 9,613 students. These figures are a troublesome statistical truth for the private higher education sector in Taiwan. Hence, many are now trying to find ways either to restructure its course programs or to attract international student enrolments. 
Ching, G. S.

Table 3

Total student population from 2011 to 2019

\begin{tabular}{cllll}
\hline School year & \multicolumn{2}{c}{ Private HEIs } & \multicolumn{2}{c}{ Public HEIs } \\
\hline 2011 & 753,935 & & 279,050 & \\
2012 & 757,693 & $0.5 \%$ & 280,348 & $0.5 \%$ \\
2013 & 754,217 & $-0.5 \%$ & 281,317 & $0.3 \%$ \\
2014 & 753,208 & $-0.1 \%$ & 283,854 & $0.9 \%$ \\
2015 & 748,189 & $-0.7 \%$ & 287,029 & $1.1 \%$ \\
2016 & 726,066 & $-3.0 \%$ & 289,332 & $0.8 \%$ \\
2017 & 695,661 & $-4.2 \%$ & 290,266 & $0.3 \%$ \\
2018 & 672,636 & $-3.3 \%$ & 289,269 & $-0.3 \%$ \\
2019 & 643,855 & $-4.3 \%$ & 288,663 & $-0.2 \%$ \\
\hline
\end{tabular}

Source. https://stats.moe.gov.tw

As for Table 4, note that comparing 2008 to 2019 school year, it would seem that the number of both public and private universities are increasing (public: from 41 to 45 , private: from 60 to 81 ). However, careful analysis of the detailed yearly changes would depict that colleges (including junior colleges) are actually transforming, upgrading, and diversifying their course offerings and transition into either a traditional (comprehensive) university or into university of science and technology (technical vocational university). Consider the various transformation and changes; the total number of institutions has actually decreased from 160 to 152 .

Table 4

Changes in HEIs numbers

\begin{tabular}{cccccccc}
\hline \multirow{2}{*}{$\begin{array}{c}\text { School } \\
\text { Year }\end{array}$} & \multicolumn{2}{c}{ Junior colleges } & \multicolumn{2}{c}{ Colleges } & \multicolumn{2}{c}{ Universities } & \multirow{2}{*}{ Overall } \\
\cline { 2 - 6 } & Private & Public & Private & Public & Private & Public & 160 \\
2008 & 12 & 3 & 37 & 7 & 60 & 41 & 162 \\
2009 & 12 & 3 & 35 & 8 & 63 & 41 & 161 \\
2010 & 12 & 3 & 30 & 5 & 67 & 44 & 161 \\
2011 & 12 & 3 & 27 & 4 & 70 & 45 & 162 \\
2012 & 12 & 2 & 24 & 4 & 73 & 47 & 161 \\
2013 & 12 & 2 & 22 & 3 & 75 & 47 & 159 \\
2014 & 12 & 2 & 20 & 1 & 76 & 48 & 158 \\
2015 & 11 & 2 & 18 & 1 & 78 & 48 & 158 \\
2016 & 11 & 2 & 18 & 1 & 78 & 48 & 157 \\
2017 & 11 & 2 & 14 & 1 & 82 & 47 & 153 \\
2018 & 10 & 2 & 13 & 1 & 82 & 45 & 152 \\
2019 & 10 & 2 & 13 & 1 & 81 & 45 & \\
\hline
\end{tabular}

These transformations are only part of the solution for the lack of incoming students. In preparation for the decreasing number of students, there are many ongoing plans and talks of mergers between key national universities and probably closure of several low performing universities (Leung, 2013). While, at the same time, the MOE encourages HEIs to become more internationalized and start accepting more foreign students (Chou, 2014). Therefore, these additional enrollments of foreign students are seen as an opportunity to fill-up for the oversupply of Taiwan HEIs. With the numerous scholarships made available to attract international students to study in Taiwan. Still, challenges exist in the provision of an all English taught course program within a non-English speaking nation like Taiwan (Lee, 2010).

\section{Performance outcomes}

Previously, Hou et al. (2013) provided an overview of the Taiwan's research excellence initiatives together with their outcome scores, more specifically on the results of the first term of the Project for Developing Top-Notch Universities (PDTNU; also known as the Plans to Develop World-Class Research Centers). They noted the increased in most of the indicators, however fears of over stressing on research over teaching, which will ultimately change the nature of a university.

52 Consortia Academia Publishing (A partner of Network of Professional Researchers and Educators) 
Starting 2011, the MOE continued the funding of universities in order to promote world-class research centers. Table 5 shows the information regarding the second term of the PDTNU; note that funding was given twice from April 2011 to March 2014 and April 2014 to December 2016 with varying amounts per year. Also shown is the almost doubled amount of funding for the last leg of the project. Besides the regular 12 HEIs (\#1 to \#12 in Table 5), additional HEIs are funded because of their uniqueness in certain research fields; inclusion of 2 HEIs starting 2011 (\#13 and \#14) and 3 HEIs starting 2014 (\#15 to \#17). To clarify, these additional funding is actually for the specialized research centers within these HEIs, hence, the school itself cannot use the grant for other purposes.

\section{Table 5}

Funding and ranking performance of key HEIs in Taiwan

\begin{tabular}{|c|c|c|c|c|c|c|c|}
\hline \# & University & $0411-0314^{* 1}$ & $0414-1216^{* * 1}$ & $2012 \mathrm{QS}^{2}$ & $2015 \mathrm{QS}^{2}$ & $2012 \mathrm{ARWU}^{3}$ & $2015 \mathrm{ARWU}^{3}$ \\
\hline 1 & National Taiwan University & 103.33 & 200.00 & 80 & 70 & $101-150$ & $151-200$ \\
\hline 2 & National Cheng Kung University & 53.33 & 103.33 & 271 & 224 & 201-300 & $301-400$ \\
\hline 3 & National Tsing Hua University & 40.00 & 82.00 & 192 & 155 & $201-300$ & $201-300$ \\
\hline 4 & National Chiao Tung University & 33.34 & 68.66 & 238 & 182 & $301-400$ & $301-400$ \\
\hline 5 & National Central University & 23.33 & 47.34 & $401-450$ & 397 & $401-500$ & - \\
\hline 6 & National Yang Ming University & 16.66 & 33.34 & 285 & 338 & $401-500$ & - \\
\hline 7 & National Sun Yat-Sen University & 15.00 & 26.67 & $451-500$ & 379 & $401-500$ & $401-500$ \\
\hline 8 & National Chung Hsing University & 10.00 & 20.00 & $600+$ & $501-550$ & - & - \\
\hline 9 & Chang Gung University $^{+}$ & 6.67 & 12.67 & $451-500$ & $461-470$ & $301-400$ & $401-500$ \\
\hline 10 & National Chengchi University & 6.67 & 12.67 & $551-600$ & $651-700$ & - & - \\
\hline 11 & National Taiwan University of Sci. \& Tech. & 6.67 & 11.33 & 396 & 260 & - & - \\
\hline 12 & National Taiwan Normal University & 6.67 & 13.33 & $451-500$ & 376 & - & - \\
\hline 13 & National Taiwan Ocean University ${ }^{* * * *}$ & 3.33 & 8.33 & - & - & - & - \\
\hline 14 & National Chung Cheng University ${ }^{* * *}$ & 3.33 & 3.33 & - & - & - & - \\
\hline 15 & China Medical University ${ }^{* *+}$ & & 3.33 & - & - & $401-500$ & $301-400$ \\
\hline 16 & Taipei Medical University ${ }^{* * *+}$ & & 3.33 & 323 & $421-430$ & - & - \\
\hline 17 & Yuan Ze University ${ }^{* *+}$ & & 2.00 & - & - & - & - \\
\hline 18 & $\mathrm{Fu}$ Jen Catholic University ${ }^{+}$ & & & $601+$ & $701+$ & - & - \\
\hline
\end{tabular}

Table 5 also shows that among the funded HEIs only 4 are private institutions and 3 of which are medical universities, noting the inclination towards the field of nature and science. Data also shows that for the QS World Rankings of the funded HEIs with majority of them garnering improved standings. However, for the Academic Ranking of World Universities (ARWU) results, only 1 research center improved, while the rest either are unchanged or declined in their standing. In addition, a check for other unfunded HEIs listed in the QS World Rankings showed that only Fu Jen Catholic University was included. As with the ranking methodology are quite different between the QS World Ranking and ARWU (Huang, 2011; Marginson, 2014), hence, comparison of the results between the two system might sometimes varies.

More recently, Table 6 provides the current rankings of several top-tier HEIs in Taiwan. Within the data, we can find that science (mostly nature and medical fields) inclined universities still have the upper hand in gaining higher rankings as compared to non-science (social science or comprehensive universities). Table 6 also provided the various overall ARWU and QS rankings for 2020 and 2021. It is also noted that QS currently provide additional rankings based on domain (or subject) classification, to further cater to the needs of the different fields of study. Nonetheless, institutional rankings are evolving to provide a better picture of a university (Peterbauer, 2020).

Looking back, as with the evident nature of the PDTNU, which is to promote research excellence in HEIs, the Taiwan MOE also launched the Program for Rewarding Teaching Excellence of Universities (PRTEU; for teaching universities and university of science and technology) in order to develop other HEIs categorized as teaching and technical vocational universities. Table 7 and 8 shows the amount of funding provided for the various HEIs within the past years, together with the overall funding allocation for private institutions. Although data from each of the HEIs with regards to QS and ARWU are not available, their total outcome performance 
Ching, G. S.

can be aggregated into the entire country performance analysis. Also note that within this funding scheme, a large number of private HEIs are included. However, looking at the amount of funding, it is easy to compare the inequalities towards the teaching and technical vocational universities.

Table 6

Current rankings of top tier universities in Taiwan

\begin{tabular}{lccc}
\hline \multicolumn{1}{c}{ University } & Local ranking & ARWU 2020 & Overall QS 2021 \\
\hline China Medical University (Taichung) & $1-2$ & $201-300$ & \\
National Taiwan University & $1-2$ & $201-300$ & 66 \\
National Cheng Kung University & 3 & $301-400$ & 234 \\
National Chiao Tung University & $4-5$ & $401-500$ & 240 \\
National Tsing Hua University & $4-5$ & $401-500$ & 168 \\
Chang Gung University & $6-7$ & $501-600$ & 493 \\
National Yang Ming University & $6-7$ & $501-600$ & 298 \\
National Sun Yat-Sen University & $8-9$ & $601-700$ & 416 \\
Taipei Medical University & $8-9$ & $601-700$ & 387 \\
Kaohsiung Medical University & $10-11$ & $701-800$ & \\
National Central University & $10-11$ & $701-800$ & 465 \\
National Taiwan University of Science and Technology & 12 & $801-900$ & 267 \\
Asia University, Taiwan & $13-15$ & $901-1000$ & \\
National Chung Hsing University & $13-15$ & $901-1000$ & $601-650$ \\
National Taiwan Normal University & $13-15$ & $901-1000$ & 331 \\
National Taipei University of Science and Technology & & & 488 \\
National ChengChi University & & & $581-590$ \\
National Chung Cheng University & & & $801-1000$ \\
Fu Jen Catholic University & & & $801-1000$ \\
\hline
\end{tabular}

Source. http://www.shanghairanking.com/ and https://www.topuniversities.com/university-rankings

Table 7

Funding for teaching and technical vocational universities

\begin{tabular}{lccc|lccc}
\hline \multirow{2}{*}{ Year } & \multicolumn{3}{c|}{ University $^{*}$} & \multirow{2}{*}{ Year } & \multicolumn{3}{c}{ Technical-vocational University } \\
\cline { 2 - 4 } \cline { 6 - 7 } & Public & Private & Total funding & & Public & Private & Total funding $^{1}$ \\
\hline 2005 & 1 & 6 & 40.96 & 2006 & 9 & 21 & 47.34 \\
2006 & 4 & 7 & 61.67 & 2007 & 9 & 21 & 47.34 \\
2007 & 14 & 16 & 57.65 & 2008 & 9 & 22 & 45.94 \\
2008 & 12 & 17 & 58.69 & $2009-2010$ & 8 & 24 & 47.90 \\
$2009-2010$ & 11 & 20 & 74.40 & $2011-2012$ & 9 & 25 & 49.83 \\
2011 & 11 & 20 & 51.40 & $2013-2014$ & 9 & 29 & 48.27 \\
2012 & 11 & 20 & 51.64 & $2015-2016$ & 9 & 25 & 46.58 \\
2013 & 11 & 22 & 52.50 & & & & \\
2014 & 11 & 22 & 52.50 & & & & \\
2015 & 8 & 24 & 52.26 & & & & \\
2016 & 8 & 24 & 52.26 & & & & \\
\hline
\end{tabular}

Note. ${ }^{1}$ Computed in millions of USD each year using the exchange rate of 1 USD $=30$ NTD.

Source: ${ }^{*}$ http://www.csal.fcu.edu.tw/edu/program_petitionA.aspx ${ }^{* *}$ http://www.edu.tw/

Table 8

Overall funding for the private institutions

\begin{tabular}{cc|cc}
\hline School year & Funding & School year & Funding \\
\hline $2004-2005$ & 219.18 & $2011-2012$ & 189.01 \\
$2005-2006$ & 220.92 & $2012-2013$ & 182.46 \\
$2006-2007$ & 220.92 & $2013-2014$ & 183.64 \\
$2007-2008$ & 220.92 & $2014-2015$ & 185.49 \\
$2008-2009$ & 199.30 & $2015-2016$ & 187.16 \\
$2009-2010$ & 196.25 & $2016-2017$ & 193.42 \\
$2010-2011$ & 196.80 & $2017-2018$ & 194.72 \\
\hline
\end{tabular}

Note. ${ }^{1}$ Computed in millions of USD each year using the exchange rate of 1 USD $=30$ NTD.

Source. https://stats.moe.gov.tw

54 Consortia Academia Publishing (A partner of Network of Professional Researchers and Educators) 
More recently, the Taiwan MOE (2020) reported that the recent Higher Education Sprout Project (HESP) is doing quite well. The HESP is the 86.85 billion NTD (new Taiwan dollars) project starting from 2018 for five years. Its plan is to divided into two parts, the first part aims to comprehensively enhance the quality of universities and promote the diversification of higher education so as to secure students' equal right to education. The second part, which aims to reinforce international competitiveness through facilitating universities to achieve world-class status and developing cutting-edge research centers, will cooperate with the Ministry of Science and Technology together with funding support (MOE, 2020). It is hoped that the HESP is able to spark another growth surge for the institutions in Taiwan.

Looking at the entire country performance, Table 9 shows the overall annual amount of funding for research and development in Taiwan. Note that the source of funds is around 70\% to 75\% from the business enterprise sector, while the remaining is from the government. As for the expenditure, similar to around $70 \%$ to $75 \%$ is for the business enterprise sector, an average of around $15 \%$ for government research, and the remaining for HEIs (Ministry of Science and Technology, 2015). As for the overall country performance outcome, Table 9 and 10 shows the total number of articles published in the ISI databases, note the slight annual increase with the exception of 2014. Taiwan ranks around the 16th to the 17th placed globally. While, the papers in the Engineering Index (EI) shows both upward and downward fluctuations each year, however on average more than 20,000 papers are published annually. Taiwan ranks around in the 14th placed within the global EI standing.

\section{Table 9}

Ministry of Science and Technology funding and overall performance outcome

\begin{tabular}{lccccc}
\hline \multicolumn{1}{c}{ Indicator/Year } & 2010 & 2011 & 2012 & 2013 & 2014 \\
\hline R\&D expenditure $^{1^{*}}$ & 13,194 & 13,813 & 14,450 & 15,255 & 16,116 \\
\% GDP $^{*}$ & 2.80 & 2.90 & 2.95 & 3.00 & 3.00 \\
Papers in Thomson Reuters ISI $^{* *}$ & 24,401 & 26,705 & 27,061 & 27,533 & 26,946 \\
Papers in EI $^{1 *}$ Papers in Scopus $^{* * *}$ & 20,302 & 22,819 & 20,729 & 24,415 & 22,706 \\
SJR - Total citations $^{* * *}$ & 40,103 & 42,906 & 42,848 & 43,006 & 37,966 \\
\hline
\end{tabular}

Note. ${ }^{1}$ Computed in millions of USD using the exchange rate of 1 USD $=30$ NTD. Shaded figures denotes decrease in number.

Source: ${ }^{*} 2015$ Indicators of science and technology (p. 6), by Ministry of Science and Technology, 2015, Taipei: MOST.

".* http://webofknowledge.com ${ }^{* * *}$ http://www.scimagojr.com/

In addition, Table 9 and 10 also includes the total number of publications within the Scopus database and together with the total number of citations (Table 9). Results show similar upward increased with a drop on 2014, while, the global rank of Taiwan is around $\mathbf{1 5 ^ { \text { th } }}$ to the $\mathbf{1 7 ^ { \text { th } }}$ placed. As with the battle for academic citation index database between Thomson Reuters' ISI (or sometimes refer to as Web of Science) and Scopus continues, many have started to compare their impact in the ranking system (Jacsó, 2010). With the Times Higher Education (THE) ranking starting 2014 and QS have since been using Scopus as a source for publication and citation counts. As a result, many HEIs in Taiwan have also started to make available the Scopus portal within their libraries as an alternative for Web of Science. Also note that the number of papers within both databases is quite comparable with Scopus having higher inclusions than ISI. Many institutions are actually looking into Scopus as a basis of performance indicators (Prathap, 2013; Yap, 2012).

\section{Table 10}

ISI and Scopus performance for the past six years

\begin{tabular}{lcc}
\hline \multicolumn{1}{c}{ Year - Month } & ISI & Scopus \\
\hline 2020 - Nov & 33,349 & \\
2019 & 36,238 & 38,038 \\
2018 & 33,697 & 36,814 \\
2017 & 33,955 & 37,715 \\
2016 & 34,582 & 38,004 \\
2015 & 33,324 & 38,609 \\
\hline
\end{tabular}


As for the reason in the decreased in performance outcome in 2014 seems uncertain, overall funding for that period actually increases or remains unchanged. However, it is noted that the number of graduate students (more specifically doctoral students) have been declining since 2010 (see Table 11). Some have noted that the over stressing on academic publication indexed in the ISI databases have also affected graduate students. Rumors of graduation requirements and faculty requiring students to submit papers to ISI journals are all just too common. In reality, Taiwan is suffering from an oversupply of graduate students, tandem with the uncertainty of future employment (Chen, 2012). In fact, even the National Taiwan University; the top university in Taiwan, is suffering from the decreased in number of doctoral students (Wu \& Chung, 2015).

\section{Table 11}

Number of graduate students enrolled in Taiwan HEIs SY 2010-2015

\begin{tabular}{ccccc|cccc}
\hline SY & \multicolumn{3}{c|}{ Incoming first year } & \multicolumn{3}{c}{ Total } \\
\cline { 2 - 8 } & PhD & \% change & Master & \% change & PhD & \% change & Master & \% change \\
\hline 2010 & 6,611 & $-3.23 \%$ & 70,866 & $0.71 \%$ & 34,178 & $1.27 \%$ & 185,000 & $0.87 \%$ \\
2011 & 6,030 & $-8.79 \%$ & 70,238 & $-0.89 \%$ & 33,686 & $-1.44 \%$ & 184,113 & $-0.48 \%$ \\
2012 & 5,688 & $-5.67 \%$ & 70,269 & $0.04 \%$ & 32,731 & $-2.84 \%$ & 183,094 & $-0.55 \%$ \\
2013 & 5,385 & $-5.33 \%$ & 66,357 & $-5.57 \%$ & 31,475 & $-3.84 \%$ & 177,305 & $-3.16 \%$ \\
2014 & 5,454 & $1.28 \%$ & 66,304 & $-0.08 \%$ & 30,549 & $-2.94 \%$ & 172,968 & $-2.45 \%$ \\
2015 & 5,321 & $-2.44 \%$ & 66,227 & $-0.12 \%$ & 29,333 & $-3.98 \%$ & 170,428 & $-1.47 \%$ \\
\hline
\end{tabular}

Source: $\underline{\text { https://stats.moe.gov.tw }}$

Looking into the status of international student enrollments, statistics from the MOE shows a steady increased of foreign students (see Table 12 for more details). It is noted that majority of the foreign degree seeking graduate students are enrolled in national HEIs with National Taiwan University of Science and Technology leading, followed by National Cheng Kung University, National Taiwan University, National Chiao Tung University, and National ChengChi University. Furthermore, the number of short-term students is increasing; gap between the degree seeking and short-term students are widening. In addition, most of the students are actually from the Asian region, such as Hong Kong and Macau, Mainland China, and other Asian countries with Malaysia as the leading source of international students.

\section{Table 12}

Number of foreign students in Taiwan HEIs SY 2010-2015

\begin{tabular}{ccccc|cccccc|c}
\hline \multirow{2}{*}{ SY } & \multicolumn{4}{c|}{ Degree seeking } & \multicolumn{5}{c|}{ Short-term } & \multirow{2}{*}{ Total } \\
\cline { 2 - 9 } & IS & OCS/HKM & China sub-total & Language & Exchange & IS $^{*}$ & China & Training & sub-total & \\
\hline 2010 & 8,801 & 13,562 & 22,363 & 12,555 & 2,259 & 1,604 & 5,316 & 1,241 & 22,975 & 45,338 \\
2011 & 10,059 & 14,045 & 928 & 25,032 & 14,480 & 3,301 & 2,265 & 11,227 & 1,540 & 32,813 & 57,845 \\
2012 & 11,554 & 15,204 & 1,864 & 28,622 & 13,898 & 3,871 & 3,163 & 15,590 & 1,743 & 38,265 & 66,887 \\
2013 & 12,597 & 17,055 & 3,554 & 33,206 & 15,510 & 3,626 & 3,915 & 21,233 & 2,160 & 46,444 & 79,650 \\
2014 & 14,063 & 20,134 & 5,881 & 40,078 & 15,526 & 3,743 & 4,758 & 27,030 & 2,510 & 53,567 & 93,645 \\
2015 & 15,792 & 22,918 & 7,813 & 46,523 & 18,645 & 3,743 & 4,758 & 34,114 & 2,399 & 63,659 & 110,182 \\
\hline
\end{tabular}

Note. IS: International students, OCS: Oversea Chinese students, HKM: Hong Kong/Macau students, Language: Mandarin Language center students, Exchange: Exchange students, Training: Short-term technical training students. $\quad$ *Self-paid short-term international students.

With the increasing number of international students, it would be a curious question to ask whether the influx of students cover for the loss of local incoming enrollments. Studies have used the push-pull model to determine why students choose Taiwan. Key finding suggests that the opportunity to study traditional Mandarin Chinese and to receive scholarships is essential pull factors in choosing Taiwan as a study abroad destination (Roberts, Chou, \& Ching, 2010). However, various studies have reported that international students in Taiwan are experiencing from both academic and personal challenges and difficulties (Ching, Chao, \& Lien, 2014; Ching, Lien, \& Chao, 2014; Chou, Roberts, \& Ching, 2012; Roberts et al., 2010). More important, current research findings have shown that some students are actually suffering from high levels of depression, anxiety, and stress (Ching, Chao et al., 2014). In reality, just within this few years, there are already several reported cases of study abroad students in Taiwan (Mainland Chinese, Hong Kong/Macau, and International) harming 
A decade of change: The past 10 years of Taiwan higher education institutions

themselves and others (Wang, 2012; Zhang \& Guo, 2014; Zhang \& Hong, 2014). Such incidents emphasizes the need on focusing on the quality of vital counseling services for foreign students and in a wider sense the quality of student-faculty interaction as against the focus only on the increasing the number international enrollments.

\section{Strategic initiatives}

After having a glimpse of the current situation (including the dilemmas) of Taiwan HEIs, the following section shall discuss the various strategic initiatives being undertaken. Such as: talks of transformation, mergers, and closure of HEIs, evolution of course offerings (affecting the academic profession and expansion of international enrollment), and the uplifting (and ensuring) the quality and usefulness of research (such as the establishment of Institutional Review Boards and Institutional Research centers).

Transformation of Taiwan HEIs - Within these few years, Taiwan HEIs has been undergoing various transformations. As with the fear of the lack of incoming students, talks of mergers and rumors of closure of some non-performing HEIs are quite alarming. Since 2000, two successful HEI mergers were accomplished. National Chiayi University (http://www.ncyu.edu.tw/) merges between National Chiayi Teachers College and National Chiayi Institute of Technology in 2000, combining the fields of education and science and technology. While, in 2008 Hualien University of Education merged into the National Dong Hwa University (http://www.ndhu.edu.tw/) and becomes the National Dong Hwa University Meilun Campus. It would seem a workable strategy which is to merge existing national college of education into the local national universities or combine two or more small colleges that are able to compliments each other's fields of specialization. As for the closure of HEIs, in 2014, 2 HEIs namely: Kao Fong College of Digital Contents and Yung Ta Institute of Technology and Commerce (http://www.ytit.edu.tw/) announced their closure due to the lack of incoming students.

According to several news reports, further plans and negotiations of HEIs mergers are also underway. Table 13 shows the various probable mergers. Although most of the talks are still in their early stages, voices of protest are already being heard from both alumni and students (Chou, 2016). Looking into the list of probable HEIs mergers, it would seem that most of the mergers are quite feasible, since with the similar in geographical location and with the difference in their field of expertise (course offerings). Hence, merger would seem a viable option to further streamline and make the institution more efficient and effective.

\section{Table 13}

HEIs undergoing plans and talks of mergers

$$
\text { HEIs mergers }
$$

1. National Tsing Hua University + National Hsinchu University of Education

2. National Kaohsiung Marine University + National Kaohsiung First University of Science and

Technology + National Kaohsiung University of Applied Sciences

3. National Yang-Ming University + National Chiao Tung University

4. National Taitung University + National Taitung Junior College

5. National Cheng Kung University + Taiwan National University of the Arts

6. National Taiwan University + National Taiwan Normal University + National Taiwan University of

Science and Technology

7. National Sun Yat-Sen University + National University of Kaohsiung

8. National ChengChi University + National Taiwan University of Science and Technology

Among the most controversial transformation are between the 3 big HEIs in Taiwan; National Taiwan University + National Taiwan Normal University + National Taiwan University of Science and Technology. However, after much controversy and protest from their students, the 3 HEIs instead formed the NTU Triangle education system; an alliance that aims to promote teaching and research activities. In essence, students from the three institutions are able to select (cross-enroll) subjects within the system. Actually, since 2008 there have been several university systems already in place. Similar with the function of the NTU Triangle system, the main objective is to share resources between each of the member school (see Table 14). 
Evolution of course offering - Besides the transformation of HEIs as a whole, course programs are also evolving. With the fear of having to close down due to lack of students, many undergraduate programs and colleges have been thinking of diversifying. An initial strategy is to enhance the use of technology in the form of open courses, such as: Open Course Ware of National Taiwan University (http://ocw.aca.ntu.edu.tw/), MOOCs of National Tsing Hua University (http://mooc.nthu.edu.tw/), and Tamkang University MOOCs (http://mooc.tku.edu.tw/). Students are also able to credit some course subjects after passing the certification examination (For more information, see http://apc.aca.ntu.edu.tw/). In this way, even Senior High School students are able to take advance university courses. Universities are able to apply special subsidy to provide incentives for faculty who are willing to participate in the project.

\section{Table 14}

University systems in Taiwan

\begin{tabular}{|c|c|c|}
\hline Year & School system & Member HEIs \\
\hline 2008 & $\begin{array}{l}\text { University System of Taiwan } \\
\text { (http://www.ust.edu.tw/) }\end{array}$ & $\begin{array}{l}\text { National Tsing Hua University, National Chiao Tung } \\
\text { University, National Central University, National Yang Ming } \\
\text { University }\end{array}$ \\
\hline 2011 & $\begin{array}{l}\text { Taiwan Comprehensive University System } \\
\text { (https://elitesports.tcus.edu.tw/) }\end{array}$ & $\begin{array}{l}\text { National Cheng Kung University, National Sun Yat-Sen } \\
\text { University, National Chung Hsing University, National Chung } \\
\text { Cheng University }\end{array}$ \\
\hline 2011 & $\begin{array}{l}\text { University System of Taipei } \\
\text { (http://ustp.tmu.edu.tw/) }\end{array}$ & $\begin{array}{l}\text { Taipei Medical University, National Taipei University of } \\
\text { Technology, National Taiwan Ocean University, National } \\
\text { Taipei University }\end{array}$ \\
\hline 2011 & $\begin{array}{l}\text { Taiwan University of Education } \\
\text { (http://www.tue.edu.tw/) }\end{array}$ & $\begin{array}{l}\text { University of Taipei, National Taichung University of } \\
\text { Education, National Pingtung University, National University of } \\
\text { Tainan, National Chiayi University, National Taitung } \\
\text { University, National Dong Hwa University }\end{array}$ \\
\hline 2012 & Mid-Taiwan University System & $\begin{array}{l}\text { Feng Chia University, Tunghai University, China Medical } \\
\text { University, Asia University, Chung Shan Medical University, } \\
\text { Providence University }\end{array}$ \\
\hline 2016 & NTU Triangle (http://triangle.ntu.edu.tw/) & $\begin{array}{l}\text { National Taiwan University, National Taiwan Normal } \\
\text { University, National Taiwan University of Science and } \\
\text { Technology }\end{array}$ \\
\hline
\end{tabular}

HEIs are also encouraged to expand its industry-university cooperation, besides the consultation of industry experts to lessen the gap between school and the industry, internship are also provided for students, while cooperative research projects are also being undertaken (for more information, see https://www.iaci.nkfust.edu.tw/). Furthermore, HEIs are also encouraging their faculty to have lesser course teaching loads and participate in hands-on industry training or complete certain industry certificates, such as: Tourist guides (for tourism and foreign language faculty), IT Industry certificates (for technology related courses, e.g. Microsoft, Cisco), and many others. In effect, course contents are able to help better prepare students for future employment. A more unique variation of this strategy is the so called Customize Employment Credit Program (for more information http://www.lhu.edu.tw/web2/order_list/introduction.html), wherein the HEI and the industry shall decide on a list of course subject students should undertake and is followed by an internship opportunity. In this way, students are able to receive a Certificate of Completion for the said credit program and at the same time gain actual work experience, which might develop into future employment opportunity.

HEIs are also transforming their course programs; a more common is the inclusion of technology into the current curriculum designs, such as the College of Arts in the National Taiwan Normal University (for more details, see http://arts.ntnu.edu.tw/en/). Many other foreseeable changes are for the Liberal Arts and Humanities, such as History and Philosophy. In addition, horizontal expansions of course offering are also encouraged. Many foreign language departments are evolving into more diverse course offerings, such as the opening of additional language of concentration besides the more common English, Japanese, Korean, and Spanish, various Asian languages can also be included.

Many HEIs are also either transforming or opening up new degree programs. Since, the MOE controls the maximum allowable number of students a university is able to enroll, further establishment of new departments are currently nearly impossible. Hence, what most HEIs will do is to accumulate all the excess or unused slots in

58 Consortia Academia Publishing (A partner of Network of Professional Researchers and Educators) 
A decade of change: The past 10 years of Taiwan higher education institutions

order to form a new class or program. For example: In a certain university, their Department of History accepts 35 new students each year, however, on average for the past 3 years, only 32 new students have enrolled, hence, the department can give up the 3 unused slots for other course program to use. To accomplish this, consultative meetings with the concern department heads and deans are undertaken. In addition, HEIs have a tendency of not hiring new tenured faculty and since most new degree programs are multi-disciplinary by nature, instead the faculty structure is derived from existing departments. For example: The Bachelor's Program in Educational Leadership and Technology Development of the Fu Jen Catholic University (for more details, see http://www.eltd.fju.edu.tw/), this degree program utilizes the already present expertise of the College of Education, which is educational leadership (from the Graduate Institute of Educational Leadership and Development) and information technology (from the department of Library and Information Science). Lastly, with the uncertainty of student enrollments, currently HEIs are also more inclined to hire contractual instead of tenured faculty. Hence, adds to the problem of future job security of doctoral graduates.

As for the expansion of international enrollments, looking at the previous statistics of foreign student, although majority of them are from the Asian region, still the importance of the English taught programs are seen. To augment this need, many HEIs are providing additional incentives for faculty that are willing to open full English taught course subjects, while many HEIs are also opening up beside their existing international Master's program, additional full English course programs and even College of International Education are being conceived. Such as: the College of International and Cross-Strait Education of the Asia University (for more details, see http://ci3.asia.edu.tw/) and the Brand and Fashion Management of the Fu Jen Catholic University (for more details, see http://www.bfm.fju.edu.tw/). In addition, many HEIs are opening up twinning programs with international partners, while others have gained the advantages of joining with various organizations, such as the University Mobility in Asia and the Pacific (UMAP) and Association of Christian Universities and Colleges in Asia (ACUCA) for sectarian HEIs.

Ensuring quality and effective researches - Within past few years, the MOE have been concern on the various issues regarding the quality and effectiveness of researches. In effect, Institutional Review Boards (IRBs) or Research Ethics Committees (RECs) are established. The objective of these centers is to provide policies and regulations of research ethical issues of various disciplines, at the same time provide training workshops, and to conduct ethics review process. Initially IRBs and/or RECs have become mandatory for medical institutions; evaluations held on 2007 have showed much improvement in its implementations. Later on in 2015 Taiwan's IRBs have participated in the Forum for Ethical Review Committees in the Asian and Western Pacific Region (FERCAP) and the Association for the Accreditation of Human Research Protection Programs (AAHRPP). As for the field of social sciences, the MOE also started to organize IRBs/RECs within HEIs. In 2014, more than 10 centers were installed, while in 2016 the MOE approved 13 centers (see Table 15 for more details).

\section{Table 15}

List of Taiwan HEIs IRBS and RECS

\begin{tabular}{|c|}
\hline Taiwan HEI Institutional Review Boards/Research Ethics Committee \\
\hline 1. National Taiwan University (http://ord.ntu.edu.tw/REC/) \\
\hline 2. China Medical University (http://61.66.117.10/2007/IRB/) \\
\hline 3. National Cheng Kung University (http://www.ncku.edu.tw/ nckuhirb/) \\
\hline 4. National Chiao Tung University (http://rec.nctu.edu.tw/) \\
\hline 5. National Tsing Hua University (http://rec.web.nthu.edu.tw/) \\
\hline 6. Fu Jen Catholic University (http://irb.rdo.fju.edu.tw/) \\
\hline 7. National Yang Ming University (http://ord.web.ym.edu.tw/files/90-1141-1.php) \\
\hline 8. National Changhua University of Education (http://rec.ncue.edu.tw/) \\
\hline 9. National Taiwan Normal University (http://www.acad.ntnu.edu.tw/) \\
\hline 10. National ChengChi University (http://rec.nccu.edu.tw/) \\
\hline 11. National Chung Cheng University (http://rec.ccu.edu.tw/) \\
\hline 12. University of Taipei (http://research1.utaipei.edu.tw/files/11-1004-1950.php) \\
\hline 13. Yuanpei University (http://hrec.ypu.edu.tw/) \\
\hline
\end{tabular}


Ching, G. S.

In 2015, the MOE started to provide grants for the establishment of Institutional Research (IR) centers. Table 16 shows the list of HEIs with IRs. With the goal of providing a more scientific (or data driven) activities in support of institutional planning, policy development, and decision making, it is hoped that by doing so a more effective governance of HEIs is undertaken.

\section{Table 16}

List of Taiwan IR centers and amount of funding in 2015

\begin{tabular}{|c|c|c|}
\hline & HEIs Institutional Research Centers & Funding $^{1}$ \\
\hline 1 & Asia University & 83.34 \\
\hline 2 & National Cheng Kung University & 83.34 \\
\hline 3 & Hsuan Chuang University & 83.34 \\
\hline 4 & National Chengchi University & 83.34 \\
\hline 5 & National Tsing Hua University & 83.34 \\
\hline 6 & National Sun Yat-Sen University & 83.34 \\
\hline 7 & Feng Chia University & 83.34 \\
\hline & Soochow University & 66.66 \\
\hline & Tamkang University & 66.66 \\
\hline & National Normal University & 66.66 \\
\hline & National Taiwan Ocean University & 66.66 \\
\hline & Chung Yuan Christian University & 66.66 \\
\hline & Dayeh University & 66.66 \\
\hline & National Chiao Tung University & 66.66 \\
\hline 15 & Shih Hsin University & 66.66 \\
\hline 16 & Taipei Medical University & 66.66 \\
\hline & National University of Kaohsiung & 50.00 \\
\hline 18 & Yuan Ze University & 50.00 \\
\hline 19 & National Kaohsiung Normal University & 50.00 \\
\hline 20 & National Taipei University of Education & 50.00 \\
\hline & National Taiwan University & 50.00 \\
\hline & National Taiwan Sport University & 50.00 \\
\hline 23 & National Pingtung University & 50.00 \\
\hline & Chang Jung Christian University & 50.00 \\
\hline & National Chi Nan University & 50.00 \\
\hline & National Taitung University & 50.00 \\
\hline
\end{tabular}

\section{Conclusion}

With much having said about the current standing and strategies being implemented in Taiwan HEIs and together with the upcoming end of the two major funding schemes (PDTNU and PRTEU) in December 2016, the MOE released a new scheme on April 2015 and clarifications were made on January 2016 on the Higher Education Blueprint for the New Generation. The blueprint's goals are: Every school having its own uniqueness and hope for each individual, international fame and give glory to Taiwan, and innovation, implementation, merging, and transformation. Hence, the MOE announced the implementation of 5 projects and encourage HEIs to apply, namely: University with world-class excellence for the aspiring to become world-class institutions, technological innovation for the university of science and technology, learning innovation for the teaching focused institutions, professional focusing institutions for the specific field specialists, and regional innovation and integration for the institutions who are willing to restructure and merge. Within these project applications, HEIs should focus on the vision of every school having its own uniqueness and hope for each individual, international cooperation and local concern, and innovation, implementation, merging, and transformation.

All in all, with much pressure from both global and local sources, Taiwan HEIs are currently in the point wherein an opportunity to evolve is in place. With regards to the flagship university in Taiwan, there is no doubt that National Taiwan University will be the first that would come into mind, because of its prestige within the

60 Consortia Academia Publishing (A partner of Network of Professional Researchers and Educators) 
A decade of change: The past 10 years of Taiwan higher education institutions

academe. In reality, the immediate concern for the top-tier HEIs in Taiwan would be maintaining its current status, since they are not that affected by the decreasing number of students, as compared to the private HEIs. In other words, top-tier national HEIs don't fear for the lack of students, since the first one to go shall be the private HEIs and other low performing national HEIs (from what is left in the not yet been merged/transform institutions). It would be practical to say that the private HEIs will have to close down first, before the national HEIs shall be affected. However, within this dire time, the goal is to become a flagship university in your own way. Start to look back and re-think of the core competitiveness of the institution, explore what is unique and develop this uniqueness within course offerings. In essence, blending a new brand of institution that is focused on one's unique competitive advantages.

\section{References}

Branigan, T. (2012, January 23). Taiwan offers baby bonus to fix plummeting birth rate. The Guardian. http://www.theguardian.com/world/2012/jan/23/taiwan-low-birth-rate

Chang, J. (2014, September 25). Number of universities should be reduced: Education minister. China Post. http://www.chinapost.com.tw/taiwan/national/national-news/2014/09/25/417973/Number-of.htm

Chen, D.-S., \& Chang, M.-K. (2010, April 11). Higher education in Taiwan: The crisis of rapid expansion. Blog of the International Sociological Association. http://www.isa-sociology.org/universities-in-crisis/?p=417

Chen, G. (2012, June 30). Graduate talent faces challenge of joblessness. Taipei Times. http://www.taipeitimes.com/News/editorials/archives/2012/06/30/2003536589

Ching, G. S. (2013a). ISI perceptions and hard facts: An empirical study from Taiwan. In C. P. Chou (Ed.), The SSCI syndrome in higher education: A local or global phenomenon (pp. 81-92). Rotterdam: Sense Publishing. https://doi.org/10.1007/978-94-6209-407-9_5

Ching, G. S. (2013b). Unraveling issues behind ISI misconceptions: An empirical study on the practical effects of academic publication. International Journal of Research Studies in Education, 2(3), 51-64. https://doi.org/10.5861/ijrse.2012.288

Ching, G. S., Chao, P.-C., \& Lien, W.-C. (2014). Acculturative hassles and strategies: Relationship between study abroad related depression, anxiety, and stress. International Journal of Research Studies in Psychology, 3(5), 3-25. https://doi.org/10.5861/ijrsp.2014.818

Ching, G. S., Lien, W.-C., \& Chao, P.-C. (2014). Developing a scale to measure the situational changes in short-term study abroad programs. International Journal of Research Studies in Education, 3(5), 53-71. https://doi.org/10.5861/ijrse.2014.771

Chou, C. (2016). Taiwan university addresses student protestors against school merger. Retrieved from http://www.asianews.network/content/taiwan-university-addresses-student-protestors-against-school-me rger-15197

Chou, C. P. (2014, November 12). Education in Taiwan: Taiwan's colleges and universities. Brookings. http://www.brookings.edu/research/opinions/2014/11/taiwan-colleges-universities-chou

Chou, C. P., Lin, H. F., \& Chiu, Y.-J. (2013). The impact of SSCI and SCI on Taiwan's academy: An outcry for fair play. Asia Pacific Education Review, 14(1), 23-31. https://doi.org/10.1007/s12564-013-9245-1

Chou, C. P., Roberts, A., \& Ching, G. S. (2012). A study on the international students' perception and norms in Taiwan. International Journal of Research Studies in Education, 1(2), 71-84. https://doi.org/10.5861/ijrse.2012.v1i2.76

Deem, R., Mok, K. H., \& Lucas, L. (2008). Transforming higher education in whose image? Exploring the concept of the 'world-class' university in Europe and Asia. Higher Education Policy, 21, 83-97. https://doi.org/10.1057/palgrave.hep.8300179

Fulco, M. (2018, November 14). Falling population squeezes Taiwan's universities. Taiwan Business Topics. https://topics.amcham.com.tw/2018/11/falling-population-squeezes-taiwans-universities/

Green, B. (2020, January 30). Taiwan's universities are fighting for their lives as birth rates plummet. Ketagalan Media.

https://ketagalanmedia.com/2020/01/30/taiwans-universities-are-fighting-for-their-lives-as-birth-rates-p 
lummet/

Grewal, R., Dearden, J. A., \& Llilien, G. L. (2008). The university rankings game: Modeling the competition among universities for ranking. The American Statistician, 62(3), 232-237. https://doi.org/10.1198/000313008X332124

Hazelkorn, E. (2015). Rankings and the reshaping of higher education: The battle for world-class excellence (2nd ed.). New York: Palgrave MacMillan Press. https://doi.org/10.1057/9781137446671

Hou, Y.-C., Ince, M., \& Chiang, C.-L. (2013). The impact of excellence initiatives in Taiwan higher education. In Q. Wang, Y. Cheng \& N. C. Liu (Eds.), Building world-class universities: Different approaches to a shared goal (pp. 35-53). Dordrecht: Sense Publishers. https://doi.org/10.1007/978-94-6209-034-7_3

Huang, A. H.-M. (2009). Science as ideology: SSCI, TSSCI and the evaluation system of social sciences in Taiwan. Inter-Asia Cultural Studies, 10(2), 282-291. https://doi.org/10.1080/14649370902823413

Huang, M.-H. (2011). A comparison of three major academic rankings for world universities: From a research evaluation perspective. Journal of Library and Information Science, 9(1), 1-25.

Jacsó, P. (2010). Comparison of journal impact rankings in the SCImago journal and country rank and the journal citation reports databases. Online Information Review, 34(4), 642-657. https://doi.org/10.1108/14684521011073034

Lee, C. (2010). Study in Taiwan: All the rage. Taiwan Panorama, 35(4), 70-79.

Leung, M. (2013, October 10). Private universities that close must not 'profiteer'. University World News. http://www.universityworldnews.com/article.php?story=20131010135545261

Lo, W. Y. W. (2014). University rankings: Implications for higher education in Taiwan. Singapore: Springer. https://doi.org/10.1007/978-981-4560-35-1

Lynch, K. (2014). New managerialism, neoliberalism and ranking. Ethics in Science and Environmental Politics, 13(2), 141-153. https://doi.org/10.3354/esep00137

Marginson, S. (2014). University rankings and social science. European Journal of Education, 49(1), 45-59. https://doi.org/10.1111/ejed.12061

Ministry of Education [MOE]. (2020, April 21). Higher Education Sprout Project: Sustained progress and rise of universities in Taiwan. https://english.moe.gov.tw/cp-48-17299-E6CF9-1.html

Ministry of Science and Technology [MOST]. (2015). Indicators of science and technology. Taipei: Ministry of Science and Technology.

Mok, K. H., \& Chan, Y. (2008). International benchmarking with the best universities: Policy and practice in Mainland China and Taiwan. Higher Education Policy, 21, 469-486. https://doi.org/10.1057/hep.2008.21

Peterbauer, H. (2020, June 22). University rankings are evolving. But are they improving. University World News. https://www.universityworldnews.com/post.php?story=20200622094118512

Prathap, G. (2013). Benchmarking research performance of the IITs using "Web of Science" and "Scopus" bibliometric databases. Current Science, 105(8), 1134-1138.

Roberts, A., Chou, C. P., \& Ching, G. S. (2010). Contemporary trends in East Asian higher education: Dispositions of international students in a Taiwan university. Higher Education, 59(2), 149-166. https://doi.org/10.1007/s10734-009-9239-4

Salmi, J. (2009). The challenge of establishing world-class universities. Washington, DC: The World Bank. https://doi.org/10.1596/978-0-8213-7865-6

Song, M.-M., \& Tai, H.-H. (2007). Taiwan's responses to globalisation: Internationalisation and questing for world class universities. Asia Pacific Journal of Education, 27(3), 323-340. https://doi.org/10.1080/02188790701594067

Wang, Y.-H. (2012). On the eve of returning home... An American exchange student jumped to his death [huí guó qián xī... měi jí jiāo huàn shēng tiào lóu wáng]. Retrieved from http://worldjournal.com/bookmark/21080436

Wu, P.-H., \& Chung, J. (2015, October 8). Doctoral student subsidy rise eyed after ratings dip. Taipei Times. http://www.taipeitimes.com/News/taiwan/archives/2015/10/08/2003629560

Yap, C. K. (2012). The h-index in Elsevier's Scopus as an indicator of research achievement for young

62 Consortia Academia Publishing (A partner of Network of Professional Researchers and Educators) 
A decade of change: The past 10 years of Taiwan higher education institutions

Malaysian scientists. Pertanika Journal of Science and Technology, 20(2), 197-203.

Zhang, Q.-Q., \& Guo, K.-C. (2014). Female Mainland Chinese PhD student enrolled in National ChengChi

University committed suicide by putting a plastic bag over her head [zhèng dà bó shì bān nŭ lù shēng tóu tào sù jiāo dài - zì shā shēn wáng]. China Times.

http://www.chinatimes.com/realtimenews/20141112003465-260402

Zhang, Q.-Q., \& Hong, X.-C. (2014). International student from Hong Kong killed his landlord: Covering the body with a mattress [găng shēng shā fáng dōng - chuáng diàn guǒ shī]. China Times.

http://www.chinatimes.com/newspapers/20141203000765-260106 
Ching, G. S.

64 Consortia Academia Publishing (A partner of Network of Professional Researchers and Educators) 